Original paper UDC 321.64:393.7(045)

doi: $10.21464 / \mathrm{sp} 32105$

Received: April $13^{\text {th }}, 2017$

\title{
Mikołaj Sławkowski-Rode
}

University of Warsaw, Institute of Philosophy, Krakowskie Przedmieście 3, PL-00-927 Warszawa

University of Oxford, Blackfriars Hall, Oxford OX1 3LY, UK

m.slawkowski-rode@uw.edu.pl; mikolaj.slawkowski-rode@bfriars.ox.ac.uk

\section{Mourning Marginalized: Totalitarianism and the Shared World}

\begin{abstract}
In this paper I compare two attitudes to death, and the two contrasting ways of understanding mourning connected with these: one emphasizes the need to move on after loss has been suffered, the other stresses the need to reaffirm the value of what was lost. I argue that without the latter prospects for both community formation and self-determination may be damaged. I suggest this is because the death of another impoverishes the way we experience the world, threatening the continuity of mutually affirmed meanings and values which constitute the Lebenswelt. However, this effect can be mitigated through the process of mourning which attempts to reclaim this experience. I argue that one of the most devastating aspects of twentieth century totalitarianism was the thwarting of mourning understood in this way.
\end{abstract}

Key words:

mourning, loss, death, shared experience, totalitarianism, otherness, reconciliation

Mourning emphasizes the invasion of death's tormenting presence of the nearby and familiar - or more broadly of an emptiness, which has replaced the presence of a source of value and meaning like the companionship of another, a way of life, or innocence. ${ }^{1}$ There are two contrasting ways in which reconciliation with loss can develop: one emphasizes liberation from the attachment to the source of value, the other the reaffirming of it albeit in a transfigured form. The former focuses primarily on the individual who has suffered the loss while the latter stresses the value of the original bond, and its significance for individual and community self-determination.

Contemporarily the consideration of the effects of frustrated mourning is restricted to the first of these, emphasizing psychological trauma the individual suffers due to the absence of the valued object, and the inability to overcome it and 'move on' to continue with life. In this paper I will begin by a brief

1

This of course is a broad understanding of mourning. There are numerous studies of very specific phenomena all referred to by this term - some focusing on the effects of a personal loss of a beloved person, others concerned with the enactment of a 'rite of passage' ceremony by a community or tribe. The broad application of the term, which I adopt here, is justified by the fact that my interest is in the experience of loss, and its effects on both individuals and communities, which I take to be common to all phenomena properly described by it (including some reactions to being slighted, neglected or disappointed). Mourning is often analysed in this broad sense by many philosophers including Freud and Scruton, both of whom are referred to in this paper. 
look at some theories on the development and historical significance of these models, and compare standard views of their sociological and psychological underpinning. I shall consider some concerns about the process of reconciliation being unfulfilled by letting go of our attachments too hastily and radically, or by the failure to reaffirm the value of what has been lost. I will suggest that this latter form of upset mourning contributes to the disintegration of bonds which constitute a frame of reference for both individual and group determination. This frame of reference, I will argue, is a shared experience of the world through which otherness is overcome, and mutually affirmed meanings and values established. The threat, and in many cases the reality, of its breakdown has in my view been one of the most morally devastating dimensions of the evil of totalitarian domination.

The two different attitudes to mourning distinguished here are represented in philosophical thought by Freud and Kierkegaard. ${ }^{2}$ Freud describes mourning as a process of liberation from the crippling grip of the cherished object which inhibits the ego. In his famous essay entitled "Mourning and Melancholia", he describes "the work which mourning performs" as a way to psychological reconciliation with loss, following the withdrawal of the libido from the attachment to the lost object. ${ }^{3}$ This process, according to Freud, is resisted by the ego which remains bound to the extinguished source of value, and withdrawn from the world, until it is able to finally supress it in the unconscious.

Freud considers the inability to overcome the loss, and lay its object to rest to result in the state of melancholia. In melancholia the ego, he argues, unable to find fulfilment and recognition in the absent object of affection, turns to self-hatred making new life, new loves and new engagement with the world difficult if not impossible. In the most severe cases this state of utter dejection and self-doubt, as Freud observes, may even lead the melancholiac to suicide. In healthy mourning, on the other hand, the fault is not found in the ego but rather in the world, now deficient and alien, and by dispelling the illusion of the world's hostility gradually leads the mourner to reconciliation, and to the reclaiming of her place in it. Ultimately in Freud's view the object which is a source of value and meaning, once lost, becomes a burden which needs to be shirked in order that the world can again become familiar and manageable.

Kierkegaard presents a very different approach to mourning. In an important section of The Works of Love, entitled "The Work of Love in Recollecting One Who is Dead", he suggests that on the contrary, even after it is gone, we have a duty towards the object of our affection to keep it alive through our love towards it. ${ }^{4}$ Whether we're able to fulfil this duty determines our own character as a human being - if we fail to do so we're exposed as emotionally and spiritually deficient, and incapable of genuine love in the first place. To illustrate his point Kierkegaard makes a parallel with the parents who only feel affection for their children insomuch as they expect to benefit from raising them in the future. He contrasts this utilitarian attitude with the clearly more commendable attitude of the parents whose love of their children does not require any such reward. There, he argues, the role of the parent finds perfect fulfilment, as it does not rely on anything external to it. However, it is only through the work of mourning that we express our love most fully and confirm the lasting nature and sincerity of our attachment. This is because, as Kierkegaard explains, mourning presupposes the impossibility of reciprocation and so paradoxically it is only in mourning, after its object is gone, that our love for the other is most perfect and pure. 
The contrast between these two approaches is the exemplary of radical shift in the perception and role of mourning, as well as attitudes towards the dead more generally, which the great anthropologist Philippe Ariès describes in his major work on this topic Western Attitudes Toward Death. ${ }^{5}$ Ariès identifies four periods in the evolution of the Western treatment of death and attitudes towards the dead. The first three periods are all characterised by the recognition of death as a necessary part of life, and its presence as formative to its various dimensions. During the first period, which dominates until the late middle ages, and is referred to by Ariès as 'Tamed Death', there is an emphasis on the inevitability of death and on preparation for it; in the second period, 'One's Own Death', the dying individual rather than the phenomenon itself comes to the forefront; and from the early eighteenth century the intimate dimension of death is accentuated and the focus shifted to the death of those closest to us in a period Ariès calls 'Thy Death'. The fourth stage of the evolution of attitudes towards death marks a fundamental change in that death becomes a taboo. ${ }^{6}$ Ariès argues that this period, 'Forbidden Death', grows out of the previous one, where death and mourning were sentimentalised, with spontaneous displays of heightened emotion eventually leading to the development of the practice of sheltering the dying from the reality of their condition, to spare them the weight of the emotional burden the mourner is forced to undertake. Eventually this protective attitude is extended to cover the relation between the mourner and the rest of society, where grief becomes shameful, and its expression treated as a sign of bad manners, or even mental instability.

Michelle Vovelle, although critical of many aspects of Ariès' analysis of the phenomenon, reaffirms his conclusion, suggesting that a significant factor in bringing about the great change in the perception of death and mourning was the great shock European societies underwent as a result of the Great War. ${ }^{7}$ The extreme emotions that survivors expressed, Vovelle argues, were soon replaced with an equally extreme avoidance of death, leading to the suppression of emotions associated with it, a response which quickly becomes the ac-

2

The comparison between the anthropology developed by Freud and Kierkegaard has been made before, and notably so by Ernest Becker in his famous The Denial of Death. I follow Becker in suggesting that Freud and Kierkegaard address similar issues in human psychology, but in my view with different conclusions. See: Ernest Becker, The Denial of Death, The Free Press, Macmillan, London 1973.

Sigmund Freud, "Mourning and Melancholia", in: James Strachey (ed.), The Standard Edition of the Complete Psychological Works of Sigmund Freud, Volume XIV (1914-1916). On the History of the Psycho-Analytic Movement, Papers on Metapsychology and Other Works, translated by James Strachey et al., The Hogarth Press, Institute of Psycho-analysis, London 1957, pp. 237-258.

4

Soren Kierkegaard, "The Work of Love in Recollecting One Who is Dead", in: The
Works of Love, translated by Howard V. Hoang, Edna H. Hong, Princeton University Press, Princeton 1988, pp. 345-359.

5

Philippe Ariès, Western Attitudes toward Death from the Middle Ages to the Present, Johns Hopkins University Press, Baltimore 1974.

6

Ariès quotes the anthropologist Geoffrey Gorer, and substantiates his claim that death has replaced sex as western society's greatest taboo. He suggests that since Modernity children are more likely to be openly taught about sex, but have become shielded from issues connected with death. See: P. Ariès, Western Attitudes toward Death from the Middle Ages to the Present, pp. 92-93.

7

Michelle Vouvelle, La Mort et l'Occident de 1300 à nos jours, Gallimard, Paris 2001. 
cepted standard in the twentieth century. Both anthropologists agree however that this revolution is undergirded by a transformation in the European value system more generally.

Ariès concludes that firstly the advance of medical science has elevated life to the status of the highest value, to be protected at all costs, making death into a failure rather than a natural end, and secondly that life itself has become something that should above all be happy and untainted by negative emotions (with mourning becoming an obstacle to this). He claims that the growing popularity of cremation is witness to this transformation as it is usually lacking in formality, reduces the ritual aspect of burial to a minimum, and denies any permanent location to the remains of the deceased - symbolically depriving the dead of any place amongst the living. ${ }^{8}$ Vovelle adds to this the cult of youth as the apotheosis of life which sees death as a scandal and turns old age, a reminder of the inevitability of the final hour, into a threat and embarrassment. He also draws attention to the dissolution of the connection between death and religious belief which previously gave death a proper place in society's broader understanding of human existence. ${ }^{9}$

The shift described by Ariès and Vovelle is visible within the Christian world as well. Comparing the old and the twentieth century "Liturgies of the Dead" Richard Conrad convincingly argues that the new "Office of the Dead" is in part a prayer for the living and in part a meditation on the Paschal Mystery intended to give the living comfort rather than a prayer for the dead, as was the case with the old "Office". ${ }^{10}$ Conrad notes that the new "Office of the Dead" has been made to conform exactly to the standard pattern of the Office eradicating any sense of difference concerning the time for which it is intended. This difference, as Conrad points out, was emphasized in the old Office, which carried with it a sense of bewildered anger at something inconceivable being allowed to happen, and fear over the implications of this event. Moreover, the old "Office of the Dead" was intended as a prayer in persona defuncti, intended to symbolize the inclusion of the dead in the praying community and to accompany the dead in spirit when it is no longer possible to do so in the flesh - in a sense a refusal to let go completely. Of course within the Christian world mourning our losses has sometimes been considered irreverent in light of God's omnipotence, and omniscience, which implies that nothing happens against God's will. However, the old "Liturgy of the Dead" emphasized that this will is not always easily understood, and that it can be equally irreverent to doubt the reality of loss entailed by death.

The consequences of this changed perspective on death and mourning has been evaluated critically in many contexts, including the ethical, psychological, and spiritual context. I would like to suggest a new perspective in which the negative consequences of unfulfilled mourning include a lowered axiological sensitivity and the closing down of the possibilities of experience. I will argue that as a result the framework of mutually affirmed meanings and values, which constitutes the shared world, is threatened, damaging prospects for both community formation and self-determination. This however should not be taken as advancing the model of mourning I take Kierkegaard to represent, as one to be adhered to exclusively. Of course the renowned British sociologist Tony Walter is right that all societies must both deny and affirm death, and his criticism of one sided approaches like Ariès' as overdrawn is largely correct. ${ }^{11}$ Death, Walter argues, is an inherently problematic experience, and all societies struggle with it. "Society must deny death if it is to get on with its everyday business, yet it must accept it if its members are to retain contact with real- 
ity" he asserts after Dumont and Foss. ${ }^{12}$ However, this does not mean that the negative effects of denying death are made less so, or that that they need to be endorsed: even if in some cases they may be difficult to avoid, the awareness of these consequences is necessary in order to address them appropriately.

An important reminder of how deeply a distorted perception of loss may affect those who are denied the opportunity to mourn is provided by the consideration of some of the devastating consequences totalitarian regimes have had on the individuals and communities which suffered under them. Amongst all other crimes committed by totalitarian domination, its brutal intrusion into the process of reconciliation with loss, which wherever it happened left a difficult legacy of confused emotions, unresolved trauma, and repressed pain, is perhaps the most difficult to deal with, and has the longest lasting effects. This is because true reconciliation with loss, and the relief from some of the suffering caused by it, comes from the ability to retain a connection with what we have lost as a source of the value and meaning which gives structure to life. When this becomes threatened, just as in Freud's diagnosis of melancholia as a kind of morbid dwelling on the beloved's demise, new life, new loves and new engagement with the world are made difficult if not impossible.

In the second part of this paper I'm going to consider the nature of the loss, and the process of reconciliation in phenomenological terms by developing an account of 'shared experience' and how it relates to the creation of meaning and value. This will give some clues for a new interpretation of the effects of the totalitarian intrusion into this most intimate sphere of human relations. I will look at how the shared world of value and meaning is created with the encounter of another and how the other's death threatens this world. I will suggest that through the process of mourning, understood as a reaffirmation of the original bond, the value and meaning of the shared world may be preserved in the experience of the individual and the community. Finally, by referring to relevant features of two great totalitarian regimes, the Nazi and the Soviet, I want to show how this world may become utterly destroyed and the values it includes lost when this form of mourning is denied.

Józef Tischner, a Polish existential theologian, greatly influenced by Kierkegaard, considers the key to axiology to be the moment of meeting another human being. He describes this moment as the 'source experience' of human ethical self-knowledge. ${ }^{13}$ Tishner refers to Levinas to explain how the other person is revealed to us through their face, and how this enables dialogue in which the world is disclosed to both as shared in its mutual experience as the Lebenswelt - or the 'life-world'. The Lebenswelt is inherently shot

P. Ariès, Western Attitudes toward Death from the Middle Ages to the Present, p. 91.

\section{9}

M. Vovelle, La Mort et l'Occident de 1300 à nos jours.

10

Richard Conrad, "Complaining to God or Soothing the Grief? - The Old and New Liturgies of the Dead Compared", Lecture, Association for Latin Liturgy, Leicester, October 2002; see also: "Thomas Aquinas on when not to accept God's will", forthcoming in The Meaning of Mourning edited by Mikołaj Sławkowski-Rode.
11

Tony Walter, "Modern Death: Taboo or not Taboo?", Sociology 25 (2/1991), pp. 293310. doi: https://doi.org/10.1177/003803859 1025002009

12

See: Richard G. Doumont, Dennis C. Foss, The American View of Death: Acceptance or Denial?, Schenkman Pub Co., Cambridge (MA) 1972.

13

See: Józef Tischner, Myślenie wedtug wartości [Thinking According to Value], Znak, Kraków 1982. 
through with meaning and purpose given to the most mundane of things by the place the other occupies in relation to them, and in relation to us: "the other's smile calls for us to respond to it with joy; the other's expression of pain prompts spontaneous concern; their suffering necessitates action", Tichner says. Tischner poetically describes the relation we have with the other, and the moral demand it puts on us, as that of 'dialogue', which is an act of offering to the other the world itself - transformed by the communion in which we exist with each other as human beings.

This communion can be understood in terms of the shared world love creates between individuals and the broader sharing of values within a culture, and which Tichner connects to the human face that opens the door to the participation in the other's experience. In psychology this phenomenon has been studied as 'joint attention'. In joint attention an object becomes irreducibly shared in the sense that we perceive it as an intentional object for the other. In ethics an analogous phenomenon has been described as the 'second person standpoint', notably by Stephen Darwall. ${ }^{14}$ Phenomenologically we could represent the sharing of experience in terms of the expanding of the individual horizon of the possibility of experience. A good way to conceptualize this is by reference to Angelika Kratzer's notion of 'projected possibilities' ${ }^{15}$ Kratzer suggests that we move through the world projecting possibilities - in every situation we find ourselves in there are possibilities projected into the future of the different outcomes the situation may have, like for example the possibilities opened up by looking at a university prospectus. Objects in the world, Kratzer says, determine possibilities in a very systematic way. ${ }^{16}$ However, we may add to this that all the possibilities opened up by encountering objects are already contained in the initial set of possibilities each of us is born with. In a very real sense, as we progress through life encountering objects in the world, the possibilities we have keep on diminishing - having chosen one university course I have forfeited all others. The feeling of the 'opening up' of new sets of possibilities seems to be an illusion generated by our limited first personal perspective on our life. I want to suggest, however, that there is an equally real sense in which some situations do open new possibilities before us: those situations that involve encounters with others in particular. The reasons for this are twofold. First, it should be noted that our experience of possibilities, their phenomenology, does not track mere possibility, but possibility that has a non-negligible chance of becoming actualized. For example, before I am accepted for a course of study at an institution of higher learning, all the possibilities attendant thereon figures little in my experience. Once I have been accepted, the degree to which those possibilities determine my experience is amplified along with their likelihood. In this sense the phenomenology of possibility tracks the metaphysics of probability. Consequently, there is a clear sense in which the feeling of the 'opening up' of a new set of possibilities is veridical. It is not just an illusion I am subject to due to my limited knowledge but a matter of fact about the world as it is present in my experience.

Secondly, some of the possibilities that open up for us in this way are of a special kind. These are the possibilities that arise from our encounters with others. In contrast to inanimate objects, others relate to the world intentionally just as we do. Furthermore, like us, they exercise agency over which possibilities are to be actualised. As a result, the possibilities opened up in our encounters with others are not merely possibilities for us, and possibilities to be actualised or not by us. They are also possibilities for another which can be brought about or prevented by another. The impact this has on our experi- 
ence of the world is deeply transformative. By sharing an intentional attitude towards an object, we have an opportunity to share in the possibilities it opens up before the other as well as before us. And just as we are free to choose which possibilities are actualized so is the other. As a result, those possibilities we experience jointly with others differ radically from those that concern us alone, being as they are, dependent on another's freedom. Thus our horizon of experience is expanded beyond what was projected by our potential encounters with the world alone.

Perhaps it might be countered that whatever new possibilities 'entered' into our horizon must have been a possibility for us in a broader sense which was just as 'potentially available' as all other possibilities at the outset. But not only does our encounter with the other bestow on these possibilities a nonnegligible likelihood, but it indexes that likelihood to the other's freedom, making my possibilities of experience dependant on theirs. The other's freedom cannot be part of our horizon of possibilities as usually experienced, for this is precisely what the horizon amounts to: the possibilities that are there for me. And so before the encounter with the other the possibilities of experiencing and interacting with objects in the meaningful ways, which suddenly light up our world now, were simply not there - not undiscovered but absent just as the other's freedom must be.

We may distinguish between mediated and unmediated possibility to make this clearer. Let's call the possibilities inherent to our very presence in the world 'unmediated possibilities'. These are the possibilities posed before us by the objects in the world we may come across. They are unmediated in the sense that any outcomes depend solely on us. The mediated possibilities are those opened up by our encounters with others. However, although this opening up is a possibility we hold within our individual horizon, whatever possibilities are brought in with it are not so confined, as they depend on the other's free will as it develops within their own horizon of possibilities. Moreover, an encounter with the same person (even in identical circumstances) will entail a different set of new possibilities for each individual. For each encounter the set of possibilities intuitively seems to be necessarily different: the specific possibilities which develop between any two individuals, or any specific group, seem to be unique if we accept that free will ultimately defines the concrete path through the world each individual takes. Steve's encounter with Jane will change her life in a different way than Steve's encounter with Judy will change hers, however not merely because of the different possibilities Judy and Jane themselves have (as would be the case with any inanimate object), but also because of Steve's possibilities being different respecting the two respective encounters. The intentionality brought into our horizon of experience by the other makes the world meaningful to us in new ways, and transforms our own experience of it by introducing values and emotions they produce which give a structure to our formation as a person. ${ }^{17}$ Simultaneously then, if the experience of value and apprehension of meaning depend on the

14

See: Stephen Darwall, The Second Person Standpoint: Morality, Respect, and Accountability, Harvard University Press, Cambridge (MA) 2006

15

For example, see: Angelika Kratzer, "Talking About Modality", interview (interviewed by
Roberta Pires De Oliveira, Ana Lúcia Pessotto), ReVEL 8 (2014), pp. 8-20.

16

Ibid. p. 15.

17

I develop this idea briefly sketched here in a forthcoming work on shared experience. 
shared world, this world will be uniquely constituted for any cultural community, and even to a degree, for any human relation.

However, if correct, this also means that without the other the very possibility of the experience of value is threatened or precluded. Tischner describes the inability to feel emotions in response to value as an 'axiological autism' (a form of face-blindness in our experience of the world). It is not only the inability to recognize the other as an autonomous subject - something other than merely a part of nature - but also an inability to see the world as a place where value is realized. Another way we might become unable to share the world with another is by a 'closing down' of possibilities of experience with their death, when the influence of the other's intentionality and freedom on our experience of the world is abruptly removed.

It has often been pointed out in both secular and religious contexts that value is inseparable from suffering, and that openness to it always involves the risk of loss and the pain associated with it. This is what John Cottingham stresses in his book Why Believe? when discussing the problem of evil. ${ }^{18} \mathrm{He}$ invokes a fragment of T. S. Eliot's Four Quartets which encapsulates this point:

"Who then devised the torment? Love.

Love is the unfamiliar Name

Behind the hands that wove

The intolerable shirt of flame

Which human power cannot remove."19

Cottingham suggests that free of this burden, relations with others would be rendered shallow by the absence of the tenderness we are capable of only when most vulnerable. This may be true, but at the same time the other person is not simply a shining meteor passing through our existence leaving behind it the same darkness it illuminated for a brief moment (however worthwhile the endurance of pain, after the other is irrevocably gone, might be made by their former presence). With the encounter with the other our world, defined subjectively by the horizon of experience, has been permanently changed. It is now through the memory of the other and their companionship that the values and meanings which it established for us continue to be accessible, and vice versa. Thus through the work of mourning, which seeks to reaffirm the strength of the original attachment, the meanings created by one's experience of the shared world can be reconstituted and the values inherent to it preserved.

From the perspective of the community this process is at the heart of the development of culture understood as a system shared meanings and values. This certainly is the vision which Wordsworth conveyed in "The Ruined Cottage". ${ }^{20}$ He sees the struggle to come to terms with loss as the ground for forming a community through reconciliation, linking mourner to mourner and mourners to the mourned. Consequently, mourning is portrayed by Wordsworth as a way both to accept the reality of death and to challenge it, making revisitation and the renewal of bonds possible: consolation, in the end, comes from affirming the value of what has been lost, and an openness to the possibility of the preservation of this value, albeit in a sublimated form in the life of the community. This is the familiar view of culture as the space of shared value and meaning connecting the living with those still unborn and those already dead. The phenomenological analysis I suggested adds to this both the vividness and intimate character of shared experience and the fragility entailed by this. I believe it is in this perspective that the horror of totalitarian domination can be perceived even more acutely and its far-reaching consequences consid- 
ered on a more intimate level both in the life of communities and individuals subjected to it.

Hannah Arendt observes in her detailed study on totalitarianism that the totalitarian regimes of the twentieth century are unique in Western history in that they denied their victims the right to remember and mourn. ${ }^{21}$ She observes that forbidding grief constitutes the totalitarian systems' most brutal invasion of the most personal spheres of life:

"The camps and the murder of political adversaries are only part of organized oblivion that not only embraces carriers of public opinion such as the spoken and the written word, but extends even to the families and friends of the victim." 22

In her harrowing descriptions of the logic of institutionalized terror she stresses that one of its aims was the destruction of culture. This was achieved by breaking up of the shared world and the intimacy of human relations as deeply as possible, by breaking up natural communities with forced deportations, the unceasing search for internal enemies, and the snuffing out of any interpersonal intimacy in the public sphere by insisting on the use of 'comrade' in all interactions. Arendt argues that in this effort to wipe out humanity for human existence the denial of mourning and the substitution of death for disappearance was the final stage:

"The concentration camps, by making death itself anonymous (making it impossible to find out whether a prisoner is dead or alive) robbed death of its meaning as the end of a fulfilled life. In a sense they took away the individual's own death, proving that henceforth nothing belonged to him and he belonged to no one. His death merely set a seal on the fact that he had never really existed." 23

Arendt believes that in this final stage of total domination a new and previously unknown threat to humanity was introduced. It is because of the fact that through the ages the memory of the defeated was preserved, and that the beaten were allowed to bury their dead, she argues, that culture could develop, and the values providing the framework of meaning for human life were not lost. This, she says, is exactly what not only comes under threat but is targeted by totalitarian rule. As a result, as Alexander Etkind observes in his excellent book on the cultural aftermath on this disappearance of memory in Soviet Russia, the identity of the whole society begins to dissolve. ${ }^{24}$ Confusion about the meaning of some historical events, the lack of records about others, and the blurred boundary between perpetrators and victims makes it difficult to reconstruct a shared understanding of the experience of totalitarianism, and what it has meant for the shaping of the community which emerged from it.

This is connected to another way totalitarianism may threaten culture: by cutting the community off from its past. This, as Roger Scruton suggests, is what has happened to Germany in relation to its Nazi history.

18

John Cottingham, Why Believe?, Continuum, London 2009, pp. 145-151.

19

Thomas Stearns Eliot, "Little Gidding" (1942), Four Quartets, Faber and Faber, London 1959, lines 207-211.

20

William Wordsworth, "The Ruined Cottage" (1814), The Poetical Works of William Wordsworth, Oxford University Press, London 1911.
21

Hannah Arendt, The Origins of Totalitarianism, Harcourt Brace \& Co., New York 1976.

22

Ibid. p. 452.

23

Ibid

24

Alexander Etkind, Warped Mourning. Stories of the Undead in the Land of the Unburied, Stanford University Press, Stanford (CA) 2013. 
"The Germany that we know from art, music and literature - the Germany of the Gothic cathedrals and the gingerbread cities, of Dürer and Grünewald, of Luther's Bible, of Goethe, Schiller, Kant and Hegel, the Germany of the romantic poets and of the greatest continuous musical tradition that the world will ever know - that Germany had been poisoned in people's thoughts by Hitler." 25

Hitler, Scruton observes, proclaimed himself and his regime the rightful heir of German civilisation, invoking its achievements as justification for the Nazi cause. When the Nazis were defeated it seemed that the German civilisation had been brought down with it. As Scruton writes:

“... although their music was not destroyed by the war, their cities - the greatest cities in Europe - were reduced to rubble, their civilian population exposed to the horrors of blanket bombing and the rapine of the Soviet Army, and the noses of the survivors rubbed in the unspeakable reality of the Holocaust. Their country was destroyed, but it was impossible to mourn it." 26

At the same time, on an even more intimate level those who had lost close ones fighting in the war could not grieve for their dead because of the guilt they had incurred. This phenomenon, Scruton calls 'the loss of loss', and it has made reconciliation with the past, and the reclaiming of the values which German culture had represented difficult, and in many cases impossible.

As I have argued, the trauma of loss comes in large part from the threat to the world we share with the other. This shared world is constituted by joint experience through which new meanings and values are discovered and created. I have suggested that this experience can be reclaimed or preserved through the process of mourning understood as a reaffirmation of our attachment to what has been lost. Impediments to this form of mourning contribute to the loss of value and meaning from the world. I have pointed to the aspects of totalitarian domination where this occurs both in the Nazi and Soviet regimes. The lesson we might draw from these examples is that we need to accept the individuals' and the wider communities' fundamental need to mourn as not only something that helps one become reconciled with the loss but to reclaim the forms of experience which are threatened by it. We might also conjecture that the change of perspective on death and mourning, which took place at the beginning of the last century made possible the rise of totalitarian domination by dissolving the framework of value and meaning western humanity depended on.

\title{
Mikołaj Sławkowski-Rode
}

Marginalizirati žaljenje: totalitarizam i zajednički svijet

\begin{abstract}
Sažetak
U radu uspoređujem dva stava prema smrti i za njih vezana dva suprotna pristupa razumijevanju žaljenja: prvi naglašava potrebu da se nakon pretrpljenog gubitka nastavlja dalje, drugi ističe potrebu ponovnog suočavanja s vrijednošću onoga što je izgubljeno. Argumentiram da bez potonjeg može doći do oštećenja prilike za oblikovanje zajednice i njeno samo-određenje. Predlažem to zato što smrt drugoga osiromašuje način doživljavanja svijeta te prijeti neprekidnosti zajednički utvrđenih značenja i vrijednosti koje konstituiraju Lebenswelt. Međutim, ovaj se efekt može ublažiti kroz proces žaljenja koji pokušava to iskustvo povratiti. Argumentiram da je jedan od najužasnijih aspekata totalitarizma dvadesetog stoljeća sprječavanje tako razumijevanog žaljenja.
\end{abstract}

\section{Ključne riječi}

žaljenje, gubitak, smrt, zajedničko iskustvo, totalitarizam, drugost, pomirenje 


\title{
Mikołaj Sławkowski-Rode
}

\section{Marginalisierung des Trauerns: Totalitarismus und die gemeinsame Welt}

\section{Zusammenfassung}

In der Arbeit parallelisiere ich zwei Einstellungen zum Tode und zwei mit ihnen im Zusammenhang stehende entgegengesetzte Ansätze zur Auffassung des Trauerns: Der Erste betont das Bedürfnis, nach dem erlittenen Verlust weiterzumachen, während der Zweite die Notwendigkeit hervorhebt, sich mit dem Wert des Verlorenen wieder zu konfrontieren. Ich argumentiere, die Abwesenheit des Letzteren könne die Beeinträchtigung der Gelegenheit zur Gestaltung einer Gemeinschaft und zu deren Selbstbestimmung mit sich bringen. Ich schlage dies vor, da der Tod des anderen die Art des Erlebnisses der Welt entwertet und die Kontinuität der gemeinsam definierten Bedeutungen und Werte, welche die Lebenswelt konstituieren, bedroht. Allerdings kann dieser Effekt durch den Prozess des Trauerns gemildert werden, wodurch versucht wird, diese Erfahrung wieder herbeizurufen. Ich begründe, einer der schrecklichsten Aspekte des Totalitarismus im zwanzigsten Jahrhundert sei die Verhinderung eines so begriffenen Trauerns.

\section{Schlüsselwörter}

Trauern, Verlust, Tod, gemeinsame Erfahrung, Totalitarismus, Anderheit, Versöhnung

\section{Mikołaj Sławkowski-Rode \\ Marginaliser le deuil : totalitarisme et monde commun}

\begin{abstract}
Résumé
Dans ce travail je compare deux attitudes envers la mort et, en lien avec elles, deux approches opposées pour comprendre le deuil : la première met l'accent sur la nécessité de continuer à vivre suite à une perte, et la seconde fait ressortir la nécessité d'une nouvelle confrontation avec la valeur de ce qui a été perdu. J'argumente que sans cette seconde approche il est possible d'en arriver à nuire à l'occasion de former une communauté et son autodétermination. Je propose cela car la mort de l'autre appauvrit notre façon de vivre le monde, et menace la continuité des significations qui ont été établies en commun et les valeurs qui constituent le Lebenswelt. Toutefois, cet effet peut être atténué à travers le processus de deuil qui tente de ramener cette expérience. J'argumente que l'un des aspects les plus horribles du totalitarisme du XXe siècle est d'empêcher la compréhension du deuil.
\end{abstract}

\section{Mots-clés}

deuil, perte, mort, expérience commune, totalitarisme, altérité, réconciliation

Roger Scruton, "What is the Best Way to Mourn?", Confessions of a Heretic, Notting Hill Editions, London 2017. 